\title{
Endocytosis and exocytosis of nanoparticles in mammalian cells
}

This article was published in the following Dove Press journal:

International Journal of Nanomedicine

6 May 2014

Number of times this article has been viewed

\author{
Nuri Oh ${ }^{1,2}$ \\ ji-Ho Park'-3 \\ 'Department of Bio and Brain \\ Engineering, ${ }^{2}$ Institute for Optical \\ Science and Technology, ${ }^{3}$ Institute for \\ the NanoCentury, Korea Advanced \\ Institute of Science and Technology \\ (KAIST), Daejeon, Republic of Korea
}

Correspondence: Ji-Ho Park Department of Bio and Brain Engineering, Institute for Optical Science and Technology, Institute for the NanoCentury, Korea Advanced Institute of Science and Technology (KAIST), Daejeon, Republic of Korea

Tel +82423504330

Email jihopark@kaist.ac.kr
Abstract: Engineered nanoparticles that can be injected into the human body hold tremendous potential to detect and treat complex diseases. Understanding of the endocytosis and exocytosis mechanisms of nanoparticles is essential for safe and efficient therapeutic application. In particular, exocytosis is of significance in the removal of nanoparticles with drugs and contrast agents from the body, while endocytosis is of great importance for the targeting of nanoparticles in disease sites. Here, we review the recent research on the endocytosis and exocytosis of functionalized nanoparticles based on various sizes, shapes, and surface chemistries. We believe that this review contributes to the design of safe nanoparticles that can efficiently enter and leave human cells and tissues.

Keywords: drug delivery, endocytosis, exocytosis, cancer cell, macrophage, nanoparticle, toxicity

\section{Introduction}

Nano-sized materials have been increasingly used in the medical field to improve the target efficiency of drugs. ${ }^{1-3}$ In order to successfully apply nanoparticles in drug delivery, their physical and chemical properties must first be understood, thereby assisting in controlling the biological responses to their use. Because drug delivery nanosystems transport pharmaceutical compounds in the body, it is important to understand their physiochemical properties to safely achieve a desired therapeutic effect.

However, these drug delivery nanosystems have shown some limitations regarding the toxicity of the nanoscale materials in the body. ${ }^{4,5}$ In order to reduce their toxicity, it is crucial to study endocytosis, exocytosis, and clearance mechanisms for nanoparticles released from the nanoparticle-drug conjugates. Nanoparticles exposed to the bloodstream interact with opsonin proteins. When opsonin proteins attach to the surface of nanoparticles, they allow macrophages of the mononuclear phagocytic system (MPS) to easily recognize the nanoparticles and hence the nanoparticles eventually accumulate in the MPS organs, such as liver and spleen. These phenomena cause low targeting efficiency and severe systemic toxicity of the drug-delivery nanosystems. Therefore, this review focuses on endocytosis and exocytosis patterns of nanoparticles in mammalian cells with respect to their size, shape, and surface chemistry (Figure 1).

\section{Nanoparticle stability}

Nanoparticles have been widely used in the fields of drug delivery and bioimaging because their size, shape, and surface properties can be precisely engineered for specific diseases. ${ }^{6,7}$ The nanoparticle surface can be modified with various targeting 


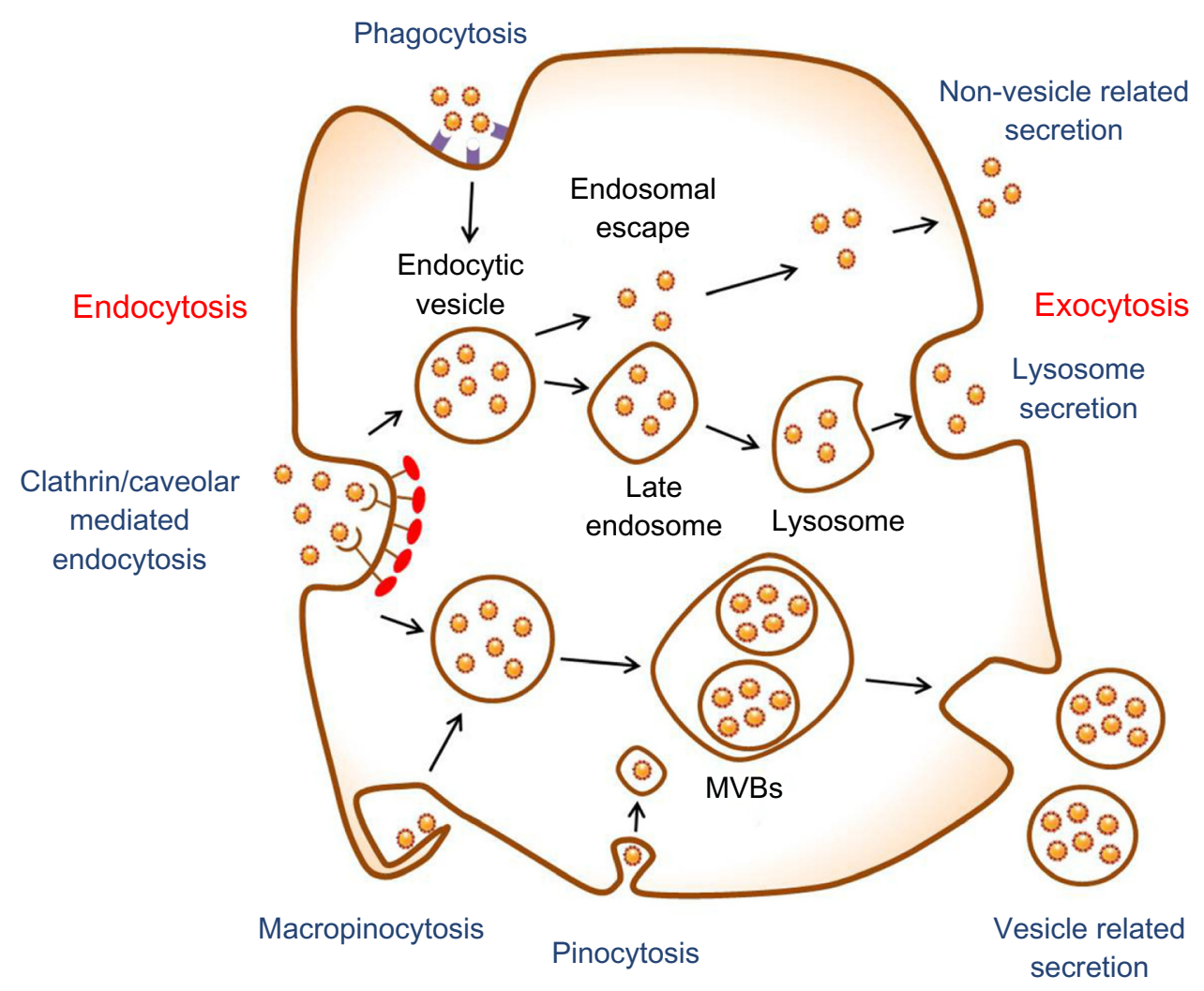

Figure I Schematic of endocytosis and exocytosis patterns of nanoparticles. Nanoparticles enter the cell via four types of pathway: clathrin/caveolar-mediated endocytosis, phagocytosis, macropinocytosis, and pinocytosis. Nanoparticles exit the cell via three types of pathway: lysosome secretion, vesicle-related secretion, and non-vesicle-related secretion.

Abbreviation: MVBs, multivesicular bodies.

molecules (eg, antibody, peptide, aptamer, etc) in order to achieve efficient targeting to disease sites.

Recently, many scientists have begun to investigate the effects of different sizes, shapes, and surface chemistries on endocytosis, toxicity, and gene regulation. ${ }^{8-10}$ However, aggregates (strongly bonded between nanoparticles) and agglomerates (loosely bonded between nanoparticles or aggregates acting under weak forces, eg, van der Waals force) formed by forces between nanoparticles and components in biological media have not been fully considered to optimize their physicochemical properties for biological applications. It was recently suggested that the aggregates or agglomerates occur when the van der Waals attractive forces between nanoparticles are larger than the electrostatic repulsive forces (Figure 2). ${ }^{11}$ Aggregated or agglomerated forms of nanoparticles would behave differently within biological systems than would nanoparticles in their single form. Thus, size uniformity of nanoparticles should be considered when the effect of physical and chemical properties of nanoparticles on their interactions with biological systems is examined.

In biological solutions, such as blood, saliva, and cell culture media, the surface chemistry of nanoparticles plays a crucial role in determining their behavior because they are directly related to types and compositions of biomolecules attached to the nanoparticle surface. The surface chemistries on the nanoparticle surface are dynamically changed because various biomolecules are attached and detached based on their binding affinity to the surface. Pre-coating of the nanoparticle surface with stabilizing molecules such as polyethylene glycol (PEG), deoxyribonucleic acid (DNA), and albumin has been utilized to reduce ionic strength and prevent nanoparticles from aggregation or agglomeration in the biological solutions. ${ }^{12-14}$

Additionally, individual nanoparticles can be naturally coated with various biomolecules, forming the nanoparticleprotein complex, when solubilized in biological solutions. The stability lifetimes of the nanoparticle-protein complexes range from hours to days in the biological solutions. The proteins covering the nanoparticle surface further prevent the individual nanoparticles from aggregation or agglomeration. Because the formation of nanoparticle-protein complexes is mainly determined by surface chemistries of the nanoparticles, it is important to investigate which surface chemistry is the most favorable to form the nanoparticle-protein complex. 


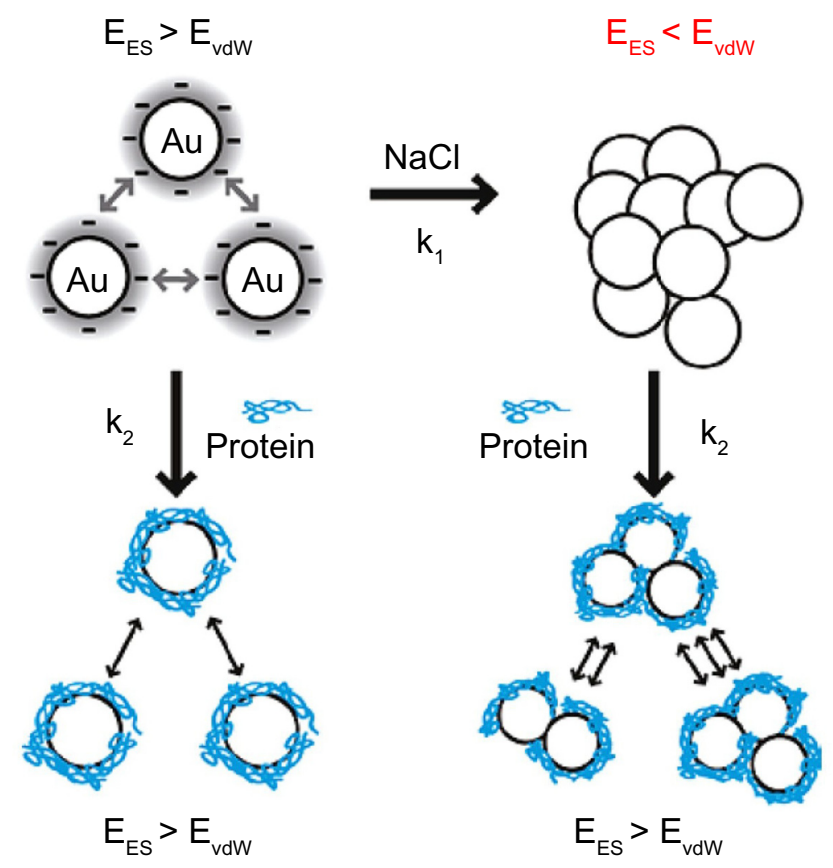

Figure 2 Scheme of aggregation or agglomeration mechanism. The stabilizing electrostatic forces $\left(E_{E S}\right)$ on the surface of bare nanoparticles are neutralized by $\mathrm{NaCl}$ ions in the biological solution, causing the van der Waals forces $\left(\mathrm{E}_{\mathrm{vdW}}\right)$ to drive formation of aggregation or agglomeration. The protein coating of nanoparticles can reduce the aggregation or agglomeration.

Note: Reproduced with permission from Albanese A, Chan WC. Effect of gold nanoparticle aggregation on cell uptake and toxicity. ACS Nano. 201 I;5:5478-5489." Copyright (c) 2011 American Chemical Society.

Therefore, natural nanoparticle-protein complexes formed in biological environments would allow us to study how individual nanoparticles interact with various types of cells.

When we study the endocytosis and exocytosis of nanoparticles, cells are treated with the nanoparticles in the culture medium containing various serum proteins. Most of the nanoparticles are first coated with the serum proteins and then met with the plasma membrane of cells. If the nanoparticles are already aggregated or agglomerated prior to binding to the membrane, their endocytosis patterns would differ from the endocytosis patterns of individual nanoparticles. The degree of aggregation or agglomeration of the nanoparticles can be determined by measuring time-dependent change of size and surface charge of the nanoparticles in the culture medium. The (hydrodynamic) size has been mainly analyzed using transmission electron microscopy (TEM) and dynamic light scattering (DLS) while the surface charge is determined by zeta potential measurements. In particular, the ultravioletvisible (UV/Vis) spectrophotometry has also been used to monitor the size of gold nanoparticles because their localized surface plasmon resonance peaks can be shifted to a longer wavelength by increasing their size. ${ }^{15}$ The DLS technique has been the most widely used to monitor size change because it directly measures hydrodynamic sizes of protein-coated nanoparticles in the biological solution with nanometer precision. Furthermore, the zeta potentials of protein-coated nanoparticles mostly appeared as a negative surface charge although the nanoparticles had different original surface chemistries. It suggests that most proteins attached on the nanoparticle surface seem to be negatively charged, regardless of their content and composition, although they may alter depending on the surface chemistries of the nanoparticles. Thus, the content and composition of proteins preferentially attached on the nanoparticle surfaces should be studied for the cellular uptake and immune response of nanoparticles. ${ }^{16,17}$

\section{Nanoparticle endocytosis Endocytosis mechanism}

All types of cells in the body use the endocytosis process to communicate with the biological environments. This process is an energy-dependent process through which cells internalize ions and biomolecules. ${ }^{18}$ In particular, the cells internalize nutrients and signaling molecules to obtain energy and interact with other cells, respectively. The endocytosis pathways are typically classified into clathrin- and caveolaemediated endocytosis, phagocytosis, macropinocytosis, and pinocytosis (Table 1). Clathrin- and caveolae-mediated

Table I Classification of endocytosis pathways

\begin{tabular}{lll}
\hline & Pathway & Definition \\
\hline $\begin{array}{l}\text { Specific pathway } \\
\text { Endocytosis } \\
\text { Phagocytosis }\end{array}$ & $\begin{array}{l}\text { Clathrin- and caveolin-mediated } \\
\text { Mannose receptor-, complement } \\
\text { receptor-, Fc } \gamma \text { receptor-, and } \\
\text { scavenger receptor-mediated }\end{array}$ & $\begin{array}{l}\text { Energy-dependent process by which cells internalize biomolecules } \\
\text { Actin-dependent endocytic process by which professional } \\
\text { phagocytes (macrophages, dendritic cells and neutrophils) engulf } \\
\text { Non-specific pathway } \\
\text { Macro-pinocytosis }\end{array}$ \\
& - & particles with sizes larger than $0.5 \mu$ m
\end{tabular}


endocytosis indicates receptor-mediated endocytosis. Many types of cells use the clathrin- and caveolae-mediated endocytosis pathways to internalize nanoscale materials, including viruses and nanoparticles. ${ }^{19-21}$ These endocytosis pathways are the most important pathways for the internalization of nanoparticles into cells because the nanoparticles are directly coated with the plasma proteins when exposed to physiological solutions. The phagocytosis pathway is used when phagocytic cells internalize foreign materials with sizes larger than $0.5 \mu \mathrm{m} .{ }^{16}$ The phagocytosis pathway is actin-dependent and restricted to professional phagocytes, such as macrophages, dendritic cells, and neutrophils. The macropinocytosis pathway is a non-specific process to internalize fluids and particles together into the cell, whereas the pinocytosis pathway absorbs biological fluids from the external environment of a cell. ${ }^{22}$ These pathways are very important to translocate single nanoparticles with sizes below $10 \mathrm{~nm}$ into the cell.

When nanoparticles are systemically administered into the body, they are confronted with many types of cells. Since nanoparticles have emerged as effective drug carriers to treat complex diseases, it has become crucial to understand nanoparticle endocytosis mechanisms. It is believed that the endocytosis efficiency of nanoparticles is dependent on the physicochemical properties, such as size, shape, and surface chemistry, as well as cell type. Thus, interaction of nanoparticles with cells depending on their physicochemical properties is discussed in the following sections.

\section{Factors affecting nanoparticle endocytosis}

Nanoparticles circulating in the bloodstream happen to meet and internalize into many types of cells through the plasma membrane. The plasma membrane is a selectively permeable membrane that transfers materials that are essential for sustaining the cell's life. Naturally, materials necessary for the cell's life, such as ions and nano-sized proteins, can pass through the lipid bilayer using specialized membrane-transport protein channels. ${ }^{23}$ Thus, the plasma membrane of cells would select the endocytosis pathways of nanoparticles depending on their size, shape, and surface chemistry (Table 2).

\section{Size}

Size-dependent cellular uptake of nanoparticles has been extensively investigated in various cell lines because the nanoparticle size has been known to be a key determinant of the uptake pathways. Many critical in vivo functions of nanoparticles, such as circulation time, targeting, internalization, and clearance, depend on their size. Thus, the cellular uptake of nanoparticles with various sizes is reviewed in this subsection.

Much interest has focused on understanding sizedependent internalization of nanoparticles in cancer cells and fibroblasts. The cellular uptake of gold nanoparticles of various sizes was studied in human cervical cancer cells (Figure 3). ${ }^{8,9,24}$ Researchers at the University of Toronto, Canada, demonstrated that uptake mechanism and saturation concentration of nanoparticles was dependent on their size. The $50 \mathrm{~nm}$ gold nanoparticles showed the most efficient cellular uptake compared with other sizes. The cellular uptake of polystyrene (PS) nanoparticles of various sizes was also tested on a human colon adenocarcinoma cell line. ${ }^{25}$ The PS nanoparticles with a size of $100 \mathrm{~nm}$ were taken up into the cells more efficiently than those with sizes of 50, 200, 500 , and 1,000 $\mathrm{nm}$. The internalization efficiency of the PS nanoparticles with a size of $50 \mathrm{~nm}$ was the lowest of all sizes. These two studies suggest that the patterns of cellular uptake could also vary according to nanoparticle material type. Although different cancer cell lines were used for each experiment, the stiffness of nanoparticles could affect their cellular uptake. Stiffer nanoparticles would interact tightly with the plasma membrane of cell, thereby causing rapid endocytosis.

Single-walled carbon nanotubes (SWNTs) coated with DNA molecules were used to investigate length-dependent cellular uptake. ${ }^{26}$ The results demonstrated that long $(660 \pm 40 \mathrm{~nm})$ and short $(130 \pm 18 \mathrm{~nm})$ SWNTs have lower uptake efficiencies in the fibroblasts than SWNTs with average lengths of $430 \pm 35 \mathrm{~nm}$ and $320 \pm 30 \mathrm{~nm}$. The SWNTs with an average length of $320 \pm 30 \mathrm{~nm}$ had the greatest uptake pattern.

In addition to endocytosis in non-phagocytic cells, much attention has recently been paid to understanding interactions between nanoparticles and phagocytic cells such as macrophages, because it could be relevant to the design of nanoparticles to avoid the immune system, thus increasing their target efficiency. Nanoparticles with sizes larger than $0.5 \mu \mathrm{m}$ have been known to enter phagocytic cells via phagocytosis pathways. Polymeric microspheres with diameters of 2-3 $\mu \mathrm{m}$ exhibited the maximal phagocytosis rate. ${ }^{27}$ Interestingly, this size range coincides with the general size of the bacteria that are the most common targets of the MPS.

On the other hand, there have been some efforts to examine size-dependent phagocytosis of nanoparticles smaller than $0.5 \mu \mathrm{m}$. Among many types of nanoparticles, lipid-based nanoparticles, including US Food and Drug Administration 
Table 2 Endocytosis of nanoparticles

\begin{tabular}{|c|c|c|c|c|c|c|}
\hline Nanoparticle & Size (dm) & $\begin{array}{l}\text { Coating } \\
\text { material }\end{array}$ & $\begin{array}{l}\text { Surface } \\
\text { charge }\end{array}$ & Cell types & Summary & Reference \\
\hline \multirow[t]{2}{*}{$\begin{array}{l}\text { Spherical } \\
\text { AuNP }\end{array}$} & $\begin{array}{l}14,50,74 \text {, and } \\
100 \mathrm{~nm}\end{array}$ & Citric acid & Negative & $\begin{array}{l}\text { Human cervical } \\
\text { cancer cell }\end{array}$ & $\begin{array}{l}50 \mathrm{~nm} \text { AuNPs had the highest } \\
\text { cellular uptake }\end{array}$ & $8,9,24$ \\
\hline & $16 \mathrm{~nm}$ & $\begin{array}{l}\text { PEG, TAT, and } \\
\text { NLS peptides }\end{array}$ & - & $\begin{array}{l}\text { Human cervical } \\
\text { cancer cell }\end{array}$ & $\begin{array}{l}\text { PEG-coated AuNPs were not } \\
\text { taken up at all by cells. TAT } \\
\text { peptides facilitated the direct } \\
\text { transfer of nanoparticles into } \\
\text { cells. NLS peptide-modified } \\
\text { AuNPs were found in the nucleus }\end{array}$ & 46 \\
\hline $\begin{array}{l}\text { Rod-shaped } \\
\text { AuNP }\end{array}$ & $\begin{array}{l}40 \times 14 \mathrm{~nm} \text { and } \\
74 \times 14 \mathrm{~nm}\end{array}$ & Citric acid & Negative & $\begin{array}{l}\text { Human cervical } \\
\text { cancer cell }\end{array}$ & $\begin{array}{l}\text { Rod-shaped nanoparticles with } \\
\text { a higher aspect ratio showed } \\
\text { lower cellular uptake than those } \\
\text { with a lower aspect ratio }\end{array}$ & 8 \\
\hline $\begin{array}{l}\text { Spherical and } \\
\text { rod-shaped } \\
\text { AuNP }\end{array}$ & $\begin{array}{l}15,50, \text { and } \\
15 \times 50 \mathrm{~nm}\end{array}$ & $\begin{array}{l}\text { PEO with either } \\
\text { hydroxyl, carboxyl, } \\
\text { or amine group }\end{array}$ & $\begin{array}{l}\text { Negative } \\
\text { or positive }\end{array}$ & $\begin{array}{l}\text { Human } \\
\text { macrophage }\end{array}$ & $\begin{array}{l}\text { Nanorods were more efficiently } \\
\text { taken up by macrophages than } \\
\text { were spherical NPs }\end{array}$ & 40 \\
\hline SPION & $6 \mathrm{~nm}$ & $\begin{array}{l}\text { Dextran, } \\
\text { aminodextran, } \\
\text { heparin, or DMSA }\end{array}$ & $\begin{array}{l}\text { Negative } \\
\text { or positive }\end{array}$ & $\begin{array}{l}\text { Human cervical } \\
\text { cancer cell }\end{array}$ & $\begin{array}{l}\text { Dextran-coated NPs were not } \\
\text { taken up by cells. DMSA-coated } \\
\text { NPs displayed low cellular uptake. } \\
\text { Heparin and aminodextran-coated } \\
\text { NPs showed the highest cellular } \\
\text { uptake }\end{array}$ & 47 \\
\hline SWNT & $130-660 \mathrm{~nm}$ & DNA & Negative & $\begin{array}{l}\text { Embryonic } \\
\text { fibroblast }\end{array}$ & $\begin{array}{l}660 \mathrm{~nm} \text { and I } 30 \mathrm{~nm} \text { SWNTs } \\
\text { showed lower cellular uptake } \\
\text { than } 430 \mathrm{~nm} \text { and } 320 \mathrm{~nm} \text { SWNTs }\end{array}$ & 26 \\
\hline Polymeric NP & $150-500 \mathrm{~nm}$ & $\mathrm{CMC}$ or $\mathrm{CH}$ & $\begin{array}{l}\text { Negative } \\
\text { or positive }\end{array}$ & $\begin{array}{l}\text { Murine } \\
\text { macrophage }\end{array}$ & $\begin{array}{l}\mathrm{CH} \text {-coated NPs showed higher } \\
\text { cellular uptake than } \\
\text { CMC-coated NPs }\end{array}$ & 32 \\
\hline PLGA NP & $260-300 \mathrm{~nm}$ & $\begin{array}{l}\text { PVA or vitamin } \\
\text { E TPGS }\end{array}$ & Negative & $\begin{array}{l}\text { Human colon } \\
\text { adeno-carcinoma } \\
\text { cell }\end{array}$ & $\begin{array}{l}\text { Cellular uptake of vitamin } \\
\text { E TPGS-coated NPs was higher } \\
\text { than that of PVA-coated NPs }\end{array}$ & 25 \\
\hline Apoferritin & $12 \mathrm{~nm}$ & - & - & $\begin{array}{l}\text { Human intestinal } \\
\text { epithelial cell }\end{array}$ & $\begin{array}{l}\text { Apoferrin enters the cell via ferritin } \\
\text { receptor-mediated endocytosis }\end{array}$ & 36 \\
\hline
\end{tabular}

Abbreviations: AuNP, gold nanoparticles; CH, chitosan hydrochloride; CMC, carboxymethyl chitosan; dm, diameter; DMSA, dimercaptosuccinic acid; DNA, deoxyribonucleic acid; NLS, nuclear localization sequence; PEG, polyethylene glycol; PEO, poly(ethylene oxide); PLGA, poly(D,L-lactide-co-glycolide); PVA, polyvinyl alcohol; SPION, superparamagnetic iron oxide nanoparticles; SWNT, single-walled carbon nanotubes; TAT, HIV tat protein transduction domain; E TPGS, Vitamin E succinated polyethylene glycol 1000.

(FDA)-approved liposomes have been of particular interest in the drug-delivery field due to their drug-loading capability and biocompatibility. Lipid nanoparticles with sizes of 20, 50, and $100 \mathrm{~nm}$ were taken up into the macrophages by complement receptor-mediated phagocytosis. ${ }^{28}$ In addition, liposomes with sizes ranging from 100 to 2,000 $\mathrm{nm}$ were also tested for their intracellular uptake in the macrophages. ${ }^{29}$ The amount of liposomes taken up by the macrophages increased with size over the range $100-1,000 \mathrm{~nm}$, but the uptake rate became constant with sizes over 1,000 nm. Size-dependent phagocytosis of gold nanoparticles was also studied in many research groups. It was reported that gold nanoparticles with sizes below $100 \mathrm{~nm}$ were phagocytosed via scavenger receptor-mediated phagocytosis. ${ }^{30}$ Tsai et al ${ }^{31}$ also demonstrated that gold nanoparticles with a size of $4 \mathrm{~nm}$ showed the highest uptake in the macrophages based on the number of nanoparticles taken up per cell, compared with those sized 11, 19, 35, and $45 \mathrm{~nm}$. The $4 \mathrm{~nm}$ gold nanoparticles exhibited the highest potency in inhibiting tumor necrosis factor (TNF)- $\alpha$ production related to TNR9-mediated innate immune systems.

Although the experimental results introduced here showed size-dependent cellular uptake of nanoparticles in many types of cells, the physical size would not be fully reflected when they meet the plasma membrane of the cell. Most nanoparticles tend to aggregate in biological solutions, increasing their overall size. The results regarding the size effect would be influenced by nanoparticle aggregation before entering the cell. Thus, it should be tested whether nanoparticles prepared to study their size-dependent endocytosis retain their singularity in the biological media before they enter the cell. 
A

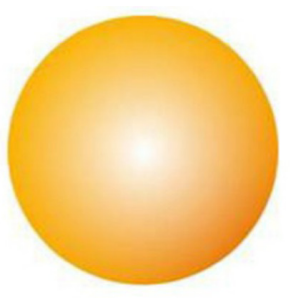

B
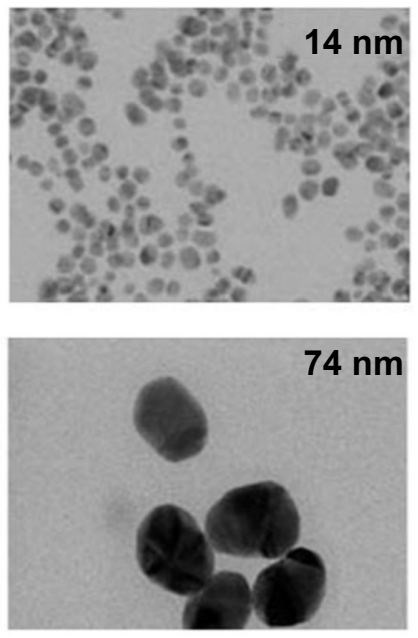

C
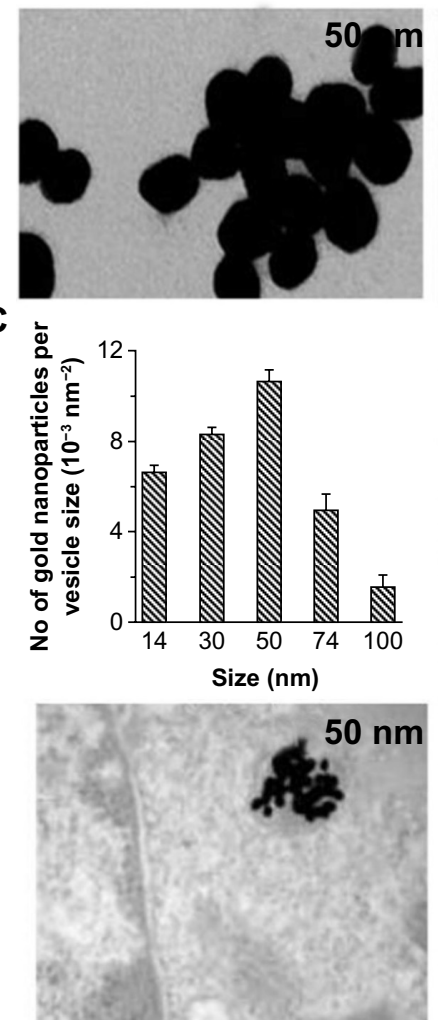
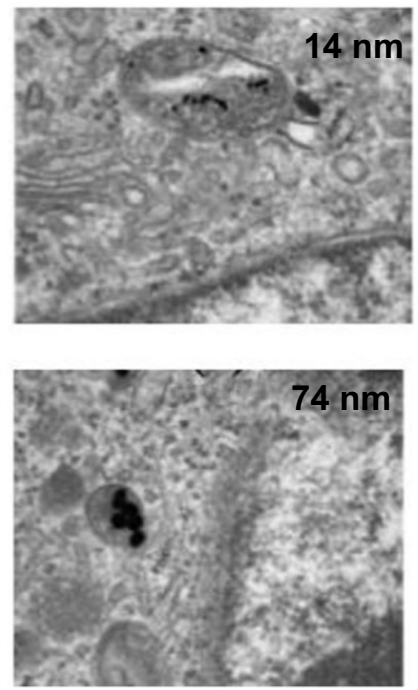
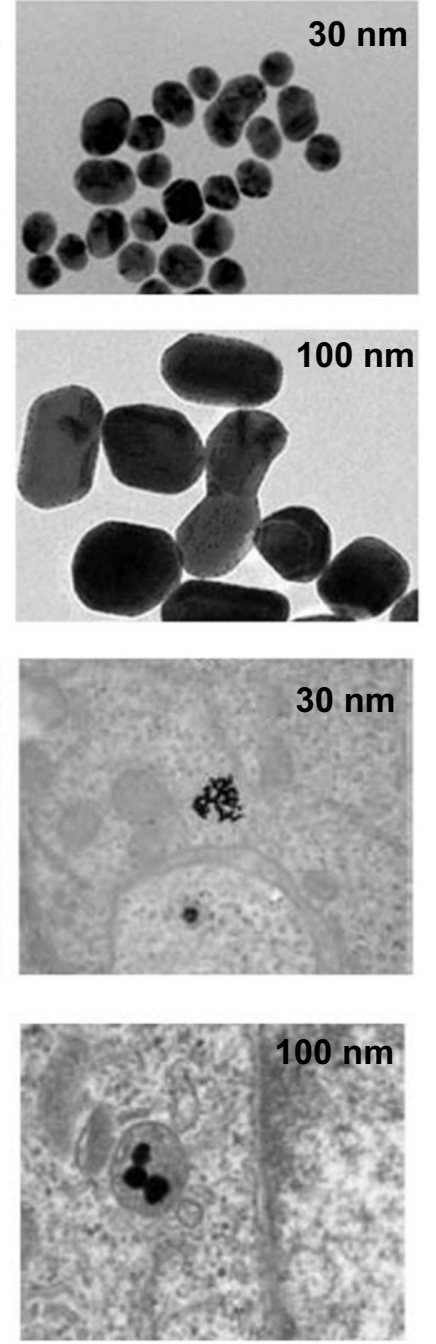

Figure 3 (A) Schematic representation of gold nanoparticles. (B) Transmission electron microscope images of citrate-coated gold nanoparticles with various sizes. (C) Transmission electron microscope images of the gold nanoparticles entrapped in cellular vesicles. Graph showing the number of the gold nanoparticles per vesicle diameter.

Note: Reproduced with permission from Chithrani BD, Ghazani AA, Chan WC. Determining the size and shape dependence of gold nanoparticle uptake into mammalian cells. Nano Lett. 2006;6:662-668. ${ }^{8}$ Copyright (C) 2007 American Chemical Society.

\section{Surface chemistry}

Surface chemistry (or surface charge) of nanoparticles can be determined by the chemical composition on the nanoparticle surface. The surface charge of nanoparticles can affect their efficiency and the pathway of cellular uptake, because biological systems consist of numerous biomolecules with various charges. Therefore, the charge of biomolecules covering the nanoparticle surface can influence the endocytosis patterns of nanoparticles. In this subsection, the effect of nanoparticle surface chemistries on the endocytosis pattern is discussed. For polymeric nanoparticles, carboxymethyl chitosan-grafted nanoparticles as negatively charged nanoparticles, and chitosan hydrochloride-grafted nanoparticles as positively charged nanoparticles, were used to test their cellular uptake efficiency. ${ }^{32}$ The different surface charges significantly affected their uptake by macrophages. The positively charged nanoparticles exhibited a higher phagocytic uptake than did the negatively or neutrally charged nanoparticles. Moreover, when the uptake efficiency of the positively charged nanoparticles was compared with that of the negatively charged, neutrally charged, and PEGylated nanoparticles, the positively and negatively charged nanoparticles were internalized more rapidly than the neutrally and PEGylated charged nanoparticles. It was also demonstrated that negatively charged polymeric nanoparticles with diameters of around $100 \mathrm{~nm}$ were more efficiently phagocytized by macrophages than positively charged nanoparticles (Figure 4).$^{33}$ Cellular uptake was also greater in the macrophages than in the monocytes.

Furthermore, the surface functionalization with PEG, poloxamer, and poloxamine polymers prevented phagocytosis because these polymers protect the nanoparticles from ionic strength, promote particle dispersion, and reduce 
A

Serum

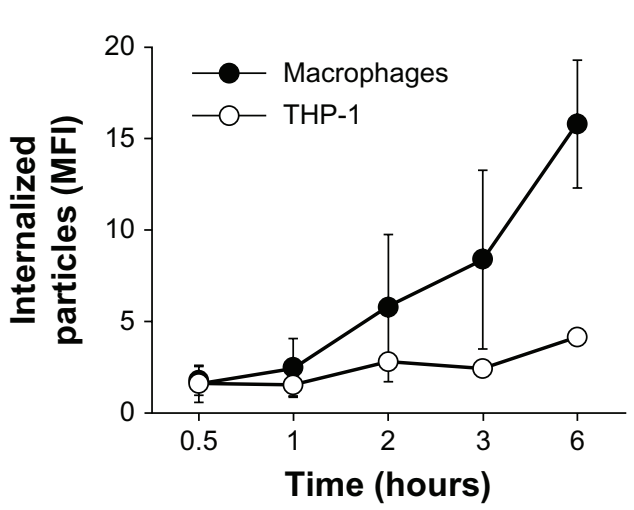

Macrophages THP-1
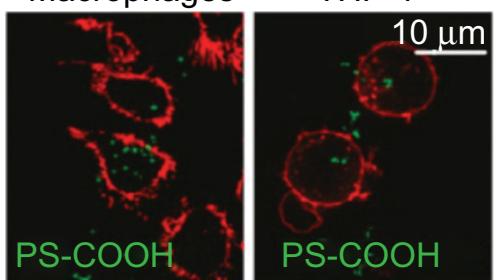

B

Serum

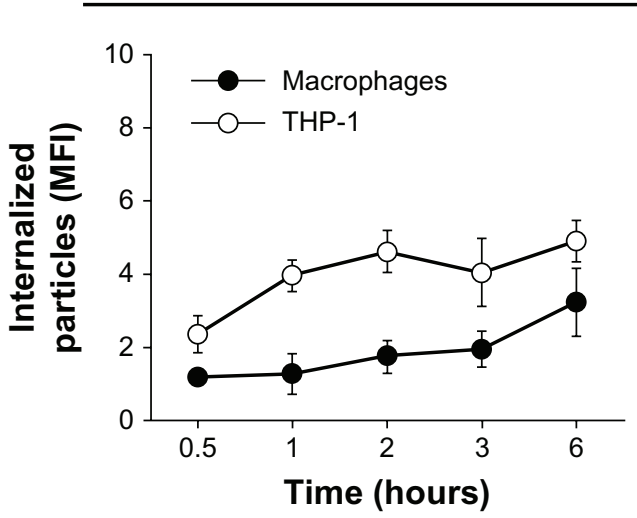

Macrophages THP-1
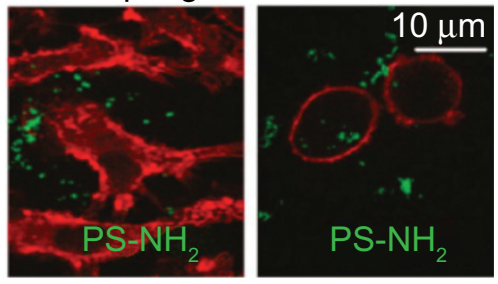

Figure 4 Kinetics of cellular uptake of negatively $(-\mathrm{COOH})(\mathbf{A})$ and positively $(-\mathrm{NH} 2)(\mathbf{B})$ charged polymeric nanoparticles in macrophages and monocytes $(\mathrm{THP}-\mathrm{I})$. Confocal fluorescence images (right) were taken after 2 hours' incubation with the indicated nanoparticles. Cell membrane was stained with red dyes and the nanoparticles were tagged with green dyes.

Note: Reproduced with permission from Lunov O, Syrovets T, Loos C, et al. Differential uptake of functionalized polystyrene nanoparticles by human macrophages and a monocytic cell line. ACS Nano. 201 I;5:1657-1669..$^{33}$ Copyright () 201 I American Chemical Society.

Abbreviation: $\mathrm{MFI}$, mean fluorescence index.

absorption of proteins in blood on their surface. ${ }^{34}$ In addition, the uptake efficiency of PEGylated nanoparticles is closely related to PEG grafting density, which can determine the protein absorption. ${ }^{17}$ That is, high PEG-grafting density inhibits protein adsorption on the nanoparticle surface in the biological solution. Interaction between nanoparticles and biological media can further lead to surface modification that eventually affects their phagocytosis through the attachment of complementary proteins and immunoglobulins. ${ }^{35}$

Recently, there has been much effort to utilize biological nanomaterials in drug delivery applications, due to their biocompatibility and natural cell-binding ability. Apoferritin, a demineralized form of ferritin, was suggested as a drug carrier because it has been known to enter the cell via ferritin receptor-mediated endocytosis. ${ }^{36,37}$ Apoferritin can be further utilized for a switchable delivery system because the endocytosis can be reversibly inhibited in various ways. Additionally, the internal cavity of apoferritin can be used to load therapeutic molecules through channels on the protein shell. Other virus- and protein-based biomaterials also have great potential to serve as biocompatible nano-platforms in the drug-delivery system. ${ }^{38}$

\section{Shape}

As mentioned in previous subsections, size and surface properties of nanoparticles play crucial roles in controlling the interaction between nanoparticles and biological systems. The nanoparticle shape might also be important in determining biological behaviors of nanoparticles. For example, it has been reported that bacteria with various shapes, such as rods, spirals, and ellipsoids, have implications for macrophage recognition. ${ }^{16}$ These shapes can directly affect the endocytosis pattern of bacteria. Recent experiments have demonstrated a shape effect of the nanoparticle on cellular uptake. ${ }^{8,39}$ Nanoscale rods exhibit the highest uptake in human cervical cancer cells, followed by spheres, 
cylinders, and cubes, and the cellular uptake of cylindrical particles depends strongly on their aspect ratio. However, the receptor-mediated endocytosis of gold nanorods was vastly decreased with increases in their aspect ratio. The comparison of intracellular uptake efficiency between rod-shaped and spherical nanoparticles has also been investigated in many types of cells. ${ }^{40}$ Interestingly, the results demonstrated that the uptake of rod-shaped nanoparticles by macrophages was more efficient than that of the spherical nanoparticles, while the spherical nanoparticles were taken up by cervical cancer cells and human lung epithelial cells more efficiently than were rod-shaped nanoparticles.

\section{Nanoparticle exocytosis}

An understanding of the cellular uptake and organ distribution of nanoparticles is important when examining their targeting and therapeutic efficiency in drug-delivery applications. Nanoparticles administered into the body are eventually cleared by organs in the MPS, such as the liver and spleen. Nanoparticles remain in these organs for a long time after being taken up by the macrophages, which increases the likelihood of unintended acute or chronic toxicity. Thus, it is also crucial to study exocytosis of the internalized nanoparticles from many types of cells, particularly macrophages, to evaluate their biosafety. However, compared with investigations of nanoparticle endocytosis, relatively little effort has been made to investigate the exocytosis of nanoparticles that may be responsible for their systemic elimination and toxicity. Thus, the exocytosis of functionalized nanoparticles is reviewed in this section (Table 3 ).

Many studies have compared the exocytosis of rodshaped nanoparticles with that of spherical nanoparticles. Chithrani and Chan $^{9}$ examined differences in exocytosis phenomena between spherical and rod-shaped gold nanoparticles using various cell types (Figure 5). The surface of gold nanoparticles was coated with transferrin proteins for their receptor-mediated endocytosis. Importantly, this work described that the cellular uptake could be considered as a result of competition between the thermodynamic driving force for wrapping and the receptor diffusion kinetics. In that respect, the $50 \mathrm{~nm}$ gold nanoparticles showed the fastest wrapping time, and therefore the receptor-ligand interaction could produce sufficient free energy to drive the nanoparticles into the cell. On the other hand, smaller nanoparticles with a slower wrapping time exhibited a faster rate of exocytosis. The exocytosis rate of the $14 \mathrm{~nm}$ nanoparticles was much faster than that of the $74 \mathrm{~nm}$ nanoparticles. In addition, the fraction of the rod-shaped nanoparticles released outside the cells

Table 3 Exocytosis of nanoparticles

\begin{tabular}{|c|c|c|c|c|c|c|}
\hline NP & Size $(\mathrm{dm})$ & $\begin{array}{l}\text { Coating } \\
\text { material }\end{array}$ & $\begin{array}{l}\text { Surface } \\
\text { charge }\end{array}$ & Cell types & Summary & Reference \\
\hline \multirow[t]{2}{*}{$\begin{array}{l}\text { Spherical } \\
\text { AuNP }\end{array}$} & $\begin{array}{l}14,50 \text {, and } \\
74 \mathrm{~nm}\end{array}$ & Transferrin & Negative & $\begin{array}{l}\text { Human fibroblast, } \\
\text { cervical cancer, } \\
\text { brain tumor cells }\end{array}$ & $\begin{array}{l}\text { Smaller NPs show a faster } \\
\text { rate of exocytosis }\end{array}$ & 9 \\
\hline & $17 \mathrm{~nm}$ & $\begin{array}{l}\text { KATWLPPR } \\
\text { and KPRQPSLP } \\
\text { peptide }\end{array}$ & Negative & Human endothelial cell & $\begin{array}{l}\text { In KATWLPPR peptide, } \\
\text { exocytosis of NPs taken up by } \\
\text { cells progressively increase until } \\
6 \text { hours. In KPRQPSLP peptides, } \\
\text { some exocytosed particles are re-taken } \\
\text { up by the cells after } 4 \text { hours }\end{array}$ & 41 \\
\hline $\begin{array}{l}\text { Rod-shaped } \\
\text { AuNP }\end{array}$ & $\begin{array}{l}20 \times 30, \\
14 \times 50, \text { and } \\
7 \times 42 \mathrm{~nm}\end{array}$ & Transferrin & Negative & $\begin{array}{l}\text { Human fibroblast, } \\
\text { cervical cancer, } \\
\text { brain tumor cells }\end{array}$ & $\begin{array}{l}\text { Nanorods with lower aspect ratios } \\
\text { showed slower exocytosis. } \\
\text { The exocytosis rate of } \\
\text { rod-shaped NPs was higher } \\
\text { than that of spherical NPs }\end{array}$ & 9 \\
\hline Quantum dot & $8 \mathrm{~nm}$ & D-penicillamine & Negative & $\begin{array}{l}\text { Human cervical } \\
\text { cancer cells }\end{array}$ & $\begin{array}{l}\text { Half-life of exocytosed fraction } \\
\text { was } 21 \text { minutes and reached } \\
\text { saturation after } 2 \text { hours }\end{array}$ & 45 \\
\hline PLGA NP & $97 \mathrm{~nm}$ & $\begin{array}{l}\text { Bovine serum } \\
\text { albumin }\end{array}$ & Negative & $\begin{array}{l}\text { Human arterial vascular } \\
\text { smooth muscle cells }\end{array}$ & $\begin{array}{l}\text { Half-life of exocytosed fraction } \\
\text { was } 30 \text { minutes }\end{array}$ & 42 \\
\hline $\begin{array}{l}\text { Polysacch } \\
\text { arides NP }\end{array}$ & $60 \mathrm{~nm}$ & Hydroxycholine & Positive & $\begin{array}{l}\text { Human bronchial } \\
\text { epithelial cell }\end{array}$ & $\begin{array}{l}\text { Cholesterol depletion blocked } \\
\text { exocytosis of NPs }\end{array}$ & 43 \\
\hline SPION & $10 \mathrm{~nm}$ & PEGylated amine & Positive & Murine macrophages & $\begin{array}{l}\text { SPIONs released from carriers } \\
\text { in the intracellular region were } \\
\text { exocytosed by membrane vesicles }\end{array}$ & 44 \\
\hline
\end{tabular}

Abbreviations: AuNP, gold nanoparticle; dm, diameter; PEG, polyethylene glycol; PLGA, poly(D,L-lactide-co-glycolide); SPION, superparamagnetic iron oxide nanoparticles; NPs, nanoparticles. 
A

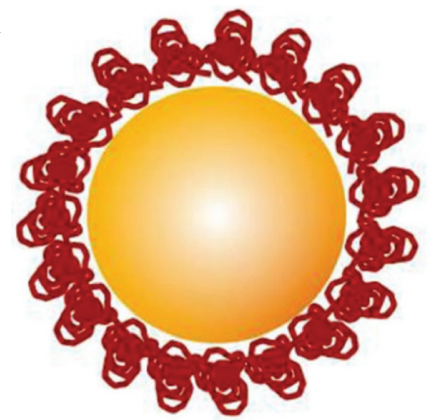

C. Transferrin

Gold nanoparticle
B

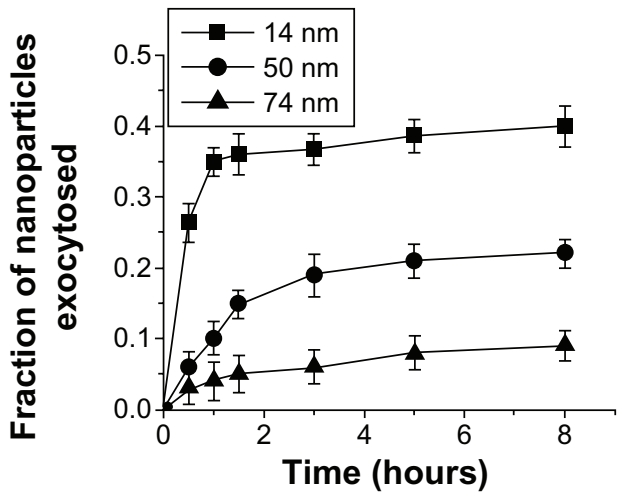

C

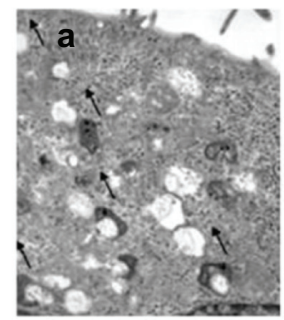

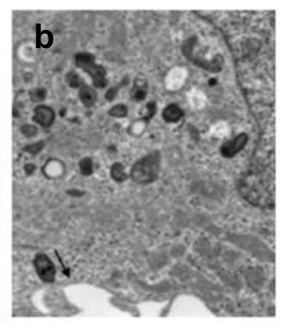
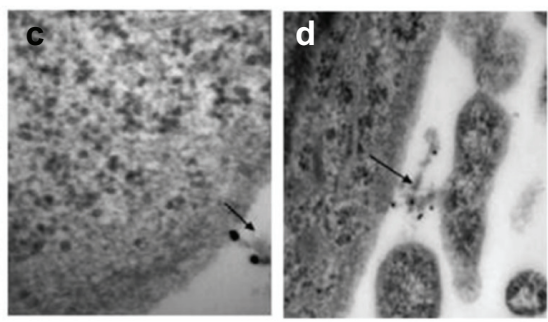

Figure 5 (A) Schematic depicting of transferrin-coated gold nanoparticles. (B) Kinetics of exocytosis patterns of the nanoparticles with different sizes. (C) Different stages of exocytosis patterns: (a) Movement of the vesicles containing nanoparticles toward the cell membrane; (b) Docking of one of the vesicles at the cell membrane; (c) Excretion of nanoparticles; (d) Cluster of nanoparticles after exocytosis.

Note: Reproduced with permission from Chithrani BD, Chan WC. Elucidating the mechanism of cellular uptake and removal of protein-coated gold nanoparticles of different sizes and shapes. Nano Lett. 2007;7:1542-1550. ${ }^{9}$ Copyright (C) 2007 American Chemical Society.

was generally higher than that of the spherical nanoparticles. The exocytosis of peptide-coated gold nanoparticles was also investigated in endothelial cells. ${ }^{41}$ Nanoparticles functionalized with KATWLPPR peptides have been known to bind to plasma membrane receptors on endothelial cells for endocytosis, while nanoparticles coated with KPRQPSLP peptides did not interact with the receptors for endocytosis. KATWLPPR peptide-coated nanoparticles taken up by cells were progressively exocytosed up until 6 hours. On the other hand, KPRQPSLP peptide-coated nanoparticles showed a more complex exocytosis profile. Interestingly, it was found that the exocytosed KPRQPSLP peptide-coated nanoparticles were re-taken up by the cells after 4 hours.

The exocytosis of poly(D,L-lactide-co-glycolide) (PLGA) nanoparticles was also examined in vascular smooth muscle cells. ${ }^{42}$ The size and zeta potential of PLGA nanoparticles coated with bovine serum albumin (BSA) were around $97 \mathrm{~nm}$ and $-20 \mathrm{mV}$, respectively. The cellular uptake of nanoparticles increased with incubation time. The exocytosis of nanoparticles increased up to $65 \%$ of the internalized fraction within 30 minutes when nanoparticles in the culture media were removed. In addition, the exocytosis of nanoparticles was found to be energy-dependent because it was significantly inhibited with sodium azide and deoxyglucose. Furthermore, authors demonstrated that the exocytosis pattern of nanoparticles was dependent on the proteins in the medium, because the proteins were carried into the cells along with the nanoparticles and interacted with biological systems inside the cells.

Exocytosis of polysaccharide cationic nanoparticles was also studied in airway epithelium cells. ${ }^{43}$ The cationic polymer hydroxycholine was used to coat nanoparticles. After the surface modification, the nanoparticles appeared to be an approximate size of $60 \mathrm{~nm}$. For exocytosis experiments, human bronchial epithelial cells were treated with the nanoparticles for 30 minutes. The amount of exocytosed nanoparticles increased significantly after 1 hour. In addition, cholesterol depletion completely blocked the exocytosis of nanoparticles, indicating that their exocytosis is cholesteroldependent.

The exocytosis patterns of superparamagnetic iron oxide nanoparticles and quantum dots were also studied in many research groups. Serda et $\mathrm{al}^{44}$ investigated the intracellular trafficking of iron oxide nanoparticles delivered into macrophage 
cells using porous silicon microcarriers (Figure 6). In the exocytosis process, the amine-functionalized nanoparticles enriched in the multivesicular bodies were incorporated into the membrane vesicles in the intracellular region and efficiently secreted from the cells 6 days after intracellular delivery. The exocytosis rate of $15 \mathrm{~nm}$ nanoparticles was faster than that of $30 \mathrm{~nm}$ nanoparticles, thus indicating that smaller nanoparticles are more favorable for exocytosis. Exocytosis of zwitterionic quantum dots was also examined in human cervical cancer cells (Figure 7). ${ }^{45}$ Quantum dots were coated with D-penicillamine to improve colloidal stability in biological solutions. The size of D-penicillamine-coated

A

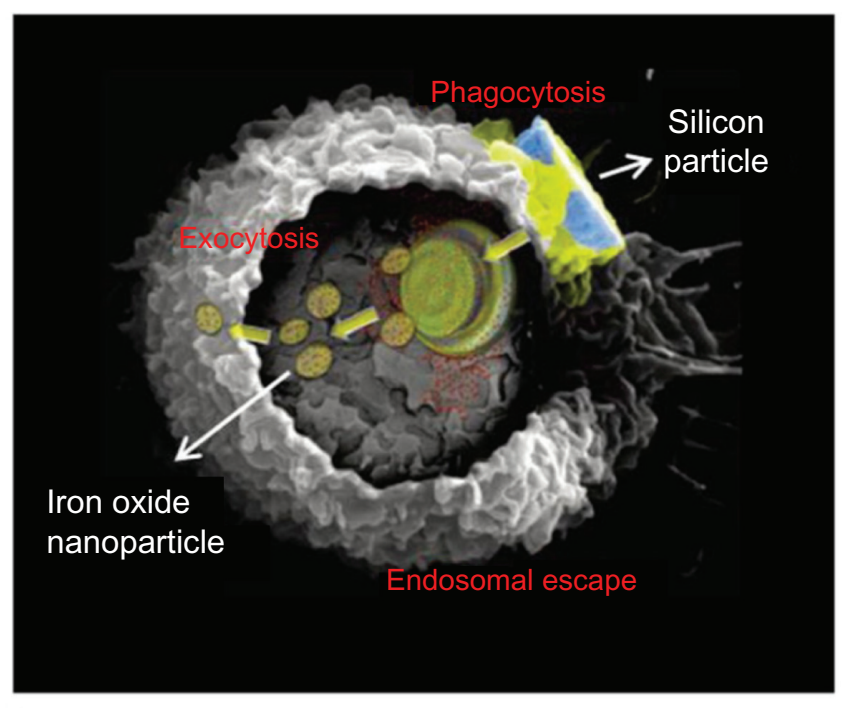

B
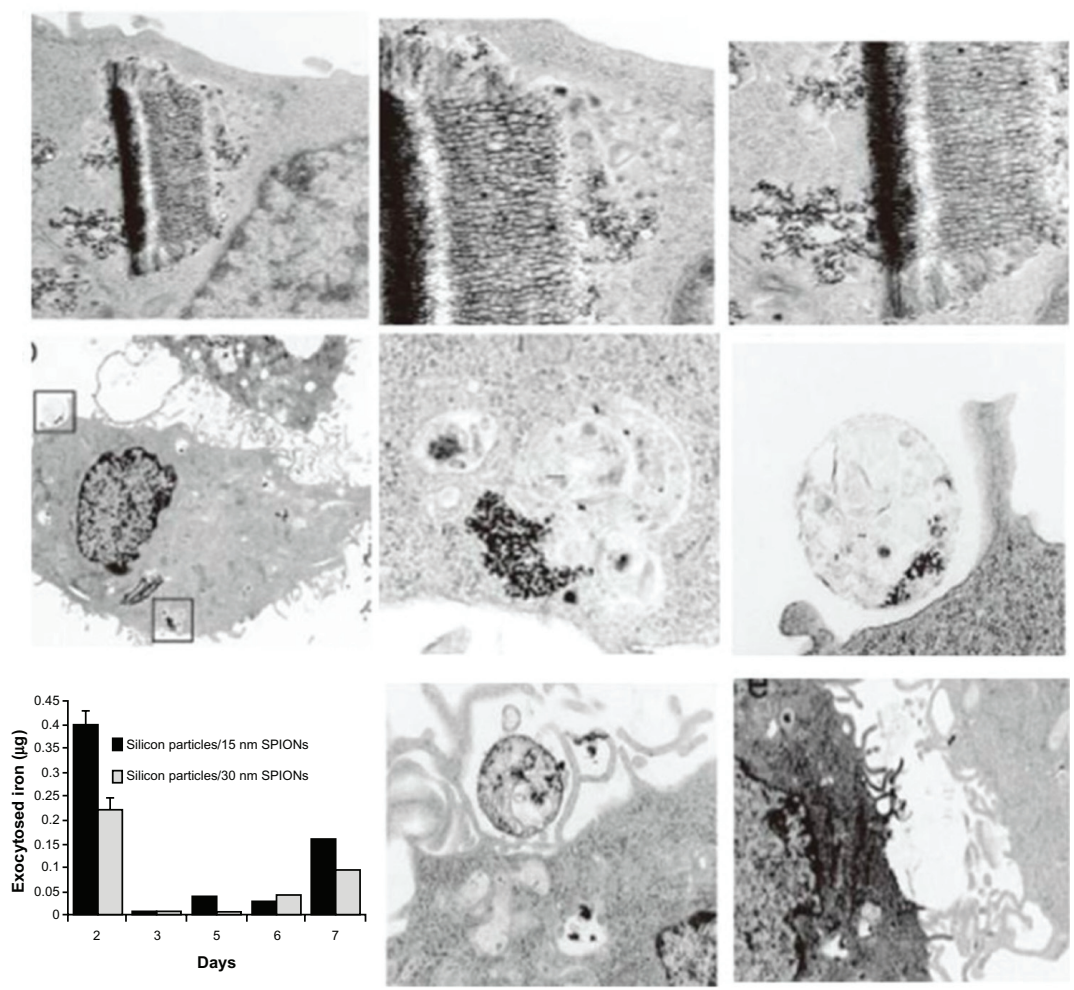

Figure 6 (A) A scanning electron microscopy image of a macrophage showing endocytosis of porous silicon particles incorporated with iron oxide nanoparticles, intracellular partitioning of the particles, endosomal escape of the particles, and exocytosis of the incorporated iron oxide nanoparticles. (B) Exocytosis of iron oxide nanoparticles. Upper column shows transmission electron microscopy images of iron oxide nanoparticles released from the porous silicon carrier in a macrophage. Middle column shows transmission electron microscopy images of the released iron oxide nanoparticles located in the intracellular region of the macrophage 6 days after uptake of the porous silicon particles. Bottom column shows that graph displayed time-dependent iron content in the supernatant and transmission electron microscopy images showed the internalized iron oxide nanoparticles were exocytosed by membrane vesicles.

Note: Reproduced with permission from Serda RE, Mack A, van de Ven AL, et al. Logic-embedded vectors for intracellular partitioning, endosomal escape, and exocytosis of nanoparticles. Small. 2010;6:269I-2700. ${ }^{44}$ Copyright @ 2010 John Wiley \& Sons, Inc. 


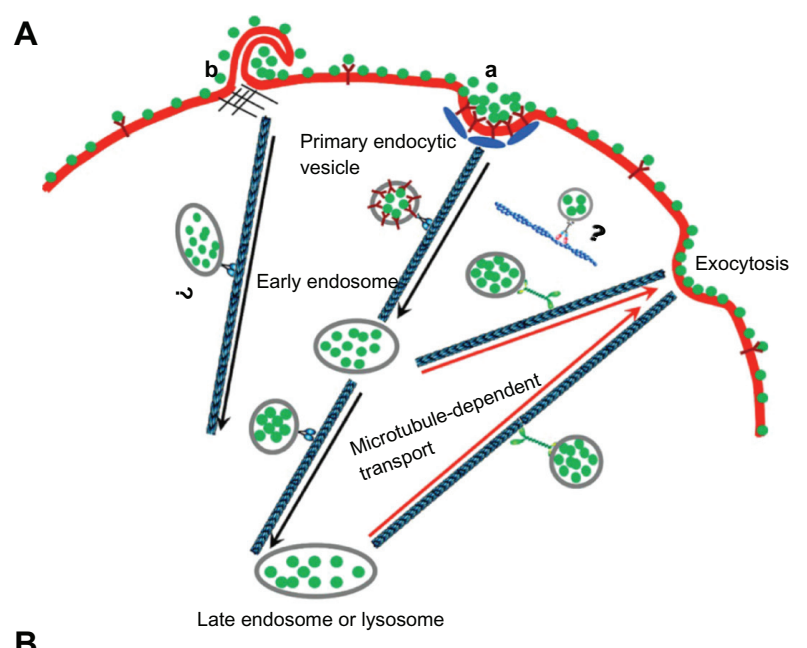

B
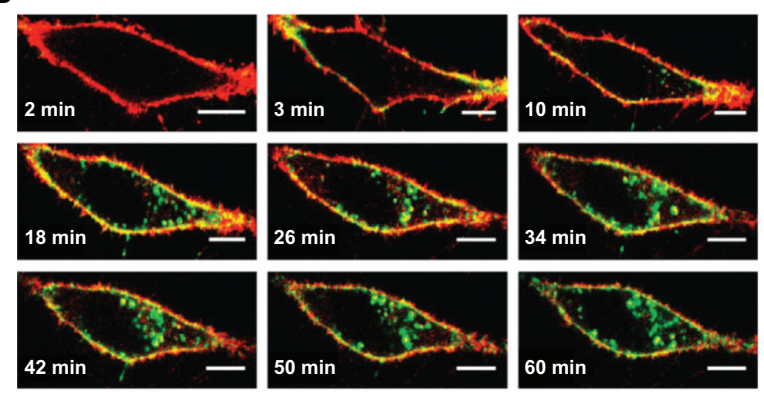

C

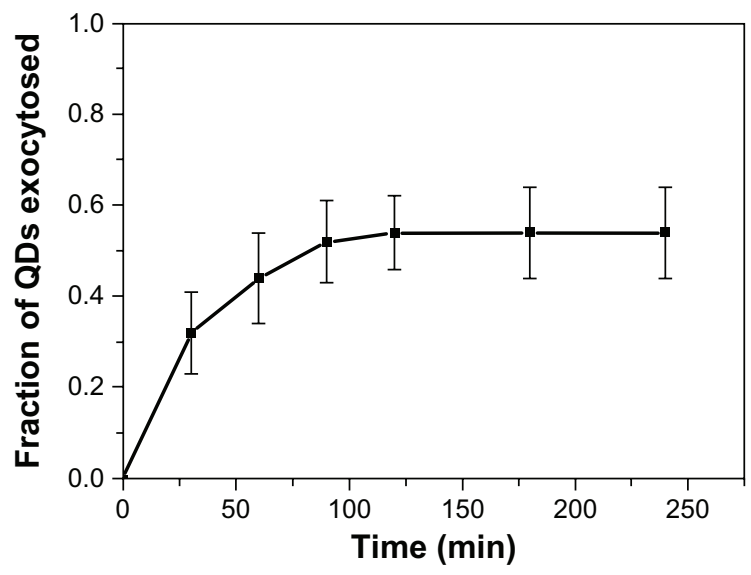

Figure 7 (A) Schematic diagram showing the endocytosis and exocytosis processes of D-penicillamine-coated quantum dots; a: Clathrin-mediated endocytosis; b: Macropinocytosis. (B) Interaction of D-penicillamine-coated quantum dots (green) with plasma membrane of a HeLa cell before internalization. The plasma membrane was stained with the red membrane dye. Scale bar: $10 \mu \mathrm{m}$. (C) Kinetics of exocytosis of D-penicillamine-coated quantum dots after removing the nanoparticles in the media. Note: Reproduced with permission from Jiang X, Röcker C, Hafner M, Brandholt S, Dörlich RM, Nienhaus GU. Endo- and exocytosis of zwitterionic quantum dot nanoparticles by live HeLa cells. ACS Nano. 2010;4:6787-6797.45 Copyright (C) 2010 American Chemical Society.

Abbreviations: QDs, quantum dots; min, minutes.

quantum dots was around $4 \mathrm{~nm}$, which is much smaller than conventional nanoparticles studied for exocytosis. In the endocytosis process, most of these smaller nanoparticles were observed on the plasma membrane prior to internalization. In addition, the quantum dots were found to enter the cells via a clathrin-mediated endocytosis pathway and macropinocytosis. In the exocytosis process, some of the quantum dots trapped in endosomes were actively transported to the cell periphery and exocytosed to the media within 21 minutes after internalization.

\section{Summary and future prospects}

This review article summarizes the endocytosis and exocytosis of nanoparticles of different sizes, shapes, and surface chemistries in many types of cells. Generally, smaller nanoparticles seem to enter and exit the cell more efficiently. Spherical nanoparticles are more favorable to be internalized into the cell than cylindrical nanoparticles. Positively charged nanoparticles exhibited much higher rates of endocytosis than negatively or neutrally charged nanoparticles, while they seem to remain in the cell longer.

Although nanoparticle-based drug delivery has been actively developed to treat complex diseases, concerns regarding nanoparticle biosafety have still been raised, limiting their clinical translations. Understanding the endocytosis of nanoparticles enables us to develop more efficient intracellular drug-delivery nanosystems, while understating their exocytosis allow us to develop more clearable delivery nanosystems after drug delivery. However, the exocytosis patterns of nanoparticles remain not yet fully understood, although the cellular uptake of nanoparticles has been studied by many research groups. Thus, a considerable amount of effort to study the endocytosis and exocytosis of nanoparticles should be made in order to develop clinically translatable targeted nanoparticles in the drug-delivery field.

\section{Acknowledgments}

This work was supported by the National Research Foundation of Korea, funded by the Ministry of Science, ICT and Future Planning (grant no 2012M3A9C6050125), the National R\&D Program for Cancer Control, Ministry for Health and Welfare (grant no 1220070), and the World Class University program funded by the Ministry of Education, Science and Technology, Republic of Korea (grant no R322008-000-10218-0).

\section{Disclosure}

The authors report no conflicts of interest in this work.

\section{References}

1. Ferrari M. Cancer nanotechnology: opportunities and challenges. Nat Rev Cancer. 2005;5(3):161-171.

2. Ruoslahti E, Bhatia SN, Sailor MJ. Targeting of drugs and nanoparticles to tumors. J Cell Biol. 2010;188(6):759-768. 
3. Jain RK, Stylianopoulos T. Delivering nanomedicine to solid tumors. Nat Rev Clin Oncol. 2010;7(11):653-664.

4. Choi HS, Liu W, Misra P, et al. Renal clearance of quantum dots. Nat Biotechnol. 2007;25(10):1165-1170.

5. Park JH, Gu L, von Maltzahn G, Ruoslahti E, Bhatia SN, Sailor MJ. Biodegradable luminescent porous silicon nanoparticles for in vivo applications. Nat Mat. 2009;8(4):331-336.

6. Niikura K, Iyo N, Matsuo Y, Mitomo H, Ijiro K. Sub-100 nm gold nanoparticle vesicles as a drug delivery carrier enabling rapid drug release upon light irradiation. ACS Appl Mater Interfaces. 2013;5: 3900-3907.

7. Yu X, Song SK, Chen J, et al. High-resolution MRI characterization of human thrombus using a novel fibrin-targeted paramagnetic nanoparticle contrast agent. Magn Reson Med. 2000;44:867-872.

8. Chithrani BD, Ghazani AA, Chan WC. Determining the size and shape dependence of gold nanoparticle uptake into mammalian cells. Nano Lett. 2006;6:662-668.

9. Chithrani BD, Chan WC. Elucidating the mechanism of cellular uptake and removal of protein-coated gold nanoparticles of different sizes and shapes. Nano Lett. 2007; 7:1542-1550.

10. Cho EC, Xie J, Wurm PA, Xia Y. Understanding the role of surface charges in cellular adsorption versus internalization by selectively removing gold nanoparticles on the cell surface with a I2/KI etchant. Nano Lett. 2009;9:1080-1084.

11. Albanese A, Chan WC. Effect of gold nanoparticle aggregation on cell uptake and toxicity. ACS Nano. 2011;5:5478-5489.

12. Gillich T, Acikgöz C, Isa L, Schlüter AD, Spencer ND, Textor M, et al. PEG-stabilized core-shell nanoparticles: impact of linear versus dendritic polymer shell architecture on colloidal properties and the reversibility of temperature-induced aggregation. ACS Nano. 2013;7: 316-329.

13. Ehrenberg MS, Friedman AE, Finkelstein JN, Oberdörster G, McGrath JL. The influence of protein adsorption on nanoparticle association with cultured endothelial cells. Biomaterials. 2009;30:603-610.

14. Park HG, Oh JH, Lee JS. Assembly-based titration for the determination of monodisperse plasmonic nanoparticle concentrations using DNA. Anal Chem. 2011;83:4989-4995.

15. Nam J, Won N, Jin H, Chung H, Kim S. pH-Induced aggregation of gold nanoparticles for photothermal cancer therapy. J Am Chem Soc. 2009;131:13639-13645.

16. Young KD. The selective value of bacterial shape. Microbiol Mol Biol Rev. 2006;70:660-703.

17. Walkey CD, Olsen JB, Guo H, Emili A, Chan WC. Nanoparticle size and surface chemistry determine serum protein adsorption and macrophage uptake. J Am Chem Soc. 2012;134:2139-2147.

18. Iversen TG, Skotland T, Sandvig K. Endocytosis and intracellular transport of nanoparticles: present knowledge and need for future studies. Nano Today. 2011;6:176-185.

19. Pelkmans L, Kartenbeck J, Helenius A. Caveolar endocytosis of simian virus 40 reveals a new two-step vesicular-transport pathway to the ER. Nat Cell Biol. 2001;3:473-483.

20. Wang Z, Tiruppathi C, Minshall RD, Malik AB. Size and dynamics of caveolae studied using nanoparticles in living endothelial cells. ACS Nano. 2009;3:4110-4116.

21. Tomatis M, Turci F, Ceschino R, et al. High aspect ratio materials: role of surface chemistry vs length in the historical "long and short amosite asbestos fibers". Inhal Toxicol. 2010;22:984-998.

22. Geiser M. Update on macrophage clearance of inhaled micro- and nanoparticles. J Aerosol Med Pulm Drug Deliv. 2010;23:207-217.

23. WoolfTB, Roux B. Structure, energetics, and dynamics of lipid-protein interactions: a molecular dynamics study of the gramicidin A channel in a DMPC bilayer. Proteins. 1996;24:92-114.

24. Jiang W, Kim BY, Rutka JT, Chan WC. Nanoparticle-mediated cellular response is size-dependent. Nat Nanotechnol. 2008;3:145-150.

25. Win KY, Feng SS. Effects of particle size and surface coating on cellular uptake of polymeric nanoparticles for oral delivery of anticancer drugs. Biomaterials. 2005;26:2713-2722.
26. Jin H, Heller DA, Sharma R, Strano MS. Size-dependent cellular uptake and expulsion of single-walled carbon nanotubes: single particle tracking and a generic uptake model for nanoparticles. ACS Nano. 2009;3:149-158.

27. Champion JA, Walker A, Mitragotri S. Role of particle size in phagocytosis of polymeric microspheres. Pharm Res. 2008;25:1815-1821.

28. Vonarbourg A, Passirani C, Saulnier P, Simard P, Leroux JC, Benoit JP, et al. Evaluation of pegylated lipid nanocapsules versus complement system activation and macrophage uptake. $J$ Biomed Mater Res A. 2006;78:620-628.

29. Chono S, Tanino T, Seki T, Morimoto K. Uptake characteristics of liposomes by rat alveolar macrophages: influence of particle size and surface mannose modification. J Pharm Pharmacol. 2007;59: $75-80$.

30. França A, Aggarwal P, Barsov EV, Kozlov SV, Dobrovolskaia MA, González-Fernández Á, et al. Macrophage scavenger receptor A mediates the uptake of gold colloids by macrophages in vitro. Nanomedicine (Lond). 2011;6:1175-1188.

31. Tsai CY, Lu SL, Hu CW, Yeh CS, Lee GB, Lei HY. Size-dependent attenuation of TLR9 signaling by gold nanoparticles in macrophages. J Immunol. 2012;188:68-76.

32. He C, Hu Y, Yin L, Tang C, Yin C. Effects of particle size and surface charge on cellular uptake and biodistribution of polymeric nanoparticles. Biomaterials. 2010;31:3657-3666.

33. Lunov O, Syrovets T, Loos C, et al. Differential uptake of functionalized polystyrene nanoparticles by human macrophages and a monocytic cell line. ACS Nano. 2011;5:1657-1669.

34. Moghimi SM. Re-establishing the long circulatory behaviour of poloxamine-coated particles after repeated intravenous administration: applications in cancer drug delivery and imaging. Biochim Biophys Acta. 1999;1472:399-403.

35. Dobrovolskaia MA, McNeil SE. Immunological properties of engineered nanomaterials. Nat Nanotechnol. 2007;2:469-478.

36. Zhang L, Fischer W, Pippel E, Hause G, Brandsch M, Knez M, et al. Receptor-mediated cellular uptake of nanoparticles: a switchable delivery system. Small. 2011;7:1538-1541.

37. Zhang L, Laug L, Münchgesang W, et al. Reducing stress on cells with apoferritin-encapsulated platinum nanoparticles. Nano Lett. 2010;10: 219-223.

38. Kaiser CR, Flenniken ML, Gillitzer E, et al. Biodistribution studies of protein cage nanoparticles demonstrate broad tissue distribution and rapid clearance in vivo. Int J Nanomedicine. 2007;2:715-733.

39. Qiu Y, Lu Y, Wang L, et al. Surface chemistry and aspect ratio mediated cellular uptake of Au nanorods. Biomaterials. 2010;31:7606-7619.

40. Bartneck M, Keul HA, Singh S, et al. Rapid uptake of gold nanorods by primary human blood phagocytes and immunomodulatory effects of surface chemistry. ACS Nano. 2010;4:3073-3086.

41. Bartczak D, Nitti S, Millar TM, Kanaras AG. Exocytosis of peptide functionalized gold nanoparticles in endothelial cells. Nanoscale. 2012;4:4470-4472.

42. Panyam J, Labhasetwar V. Dynamics of endocytosis and exocytosis of poly(D,L-lactide-co-glycolide) nanoparticles in vascular smooth muscle cells. Pharm Res. 2003;20:212-220.

43. Dombu CY, Kroubi M, Zibouche R, Matran R, Betbeder D. Characterization of endocytosis and exocytosis of cationic nanoparticles in airway epithelium cells. Nanotechnology. 2010;21:355102.

44. Serda RE, Mack A, van de Ven AL, et al. Logic-embedded vectors for intracellular partitioning, endosomal escape, and exocytosis of nanoparticles. Small. 2010;6:2691-2700.

45. Jiang X, Röcker C, Hafner M, Brandholt S, Dörlich RM, Nienhaus GU. Endo- and exocytosis of zwitterionic quantum dot nanoparticles by live HeLa cells. ACS Nano. 2010;4:6787-6797.

46. Nativo P, Prior IA, Brust M. Uptake and intracellular fate of surfacemodified gold nanoparticles. ACS Nano. 2008;2:1639-1644.

47. Villanueva A, Cañete M, Roca AG, et al. The influence of surface functionalization on the enhanced internalization of magnetic nanoparticles in cancer cells. Nanotechnology. 2009;20:115103. 
International Journal of Nanomedicine

Dovepress

\section{Publish your work in this journal}

The International Journal of Nanomedicine is an international, peerreviewed journal focusing on the application of nanotechnology in diagnostics, therapeutics, and drug delivery systems throughou the biomedical field. This journal is indexed on PubMed Central, MedLine, CAS, SciSearch ${ }^{\circledR}$, Current Contents ${ }^{\circledR} /$ Clinical Medicine,
Journal Citation Reports/Science Edition, EMBase, Scopus and the Elsevier Bibliographic databases. The manuscript management system is completely online and includes a very quick and fair peer-review system, which is all easy to use. Visit http://www.dovepress.com/ testimonials.php to read real quotes from published authors.

Submit your manuscript here: http://www.dovepress.com/international-journal-of-nanomedicine-journal 